\title{
Evidence for the Preemptive Nature of Tomato Race 3 of Xanthomonas campestris pv. vesicatoria in Florida
}

\author{
J. B. Jones, H. Bouzar, G. C. Somodi, R. E. Stall, K. Pernezny, G. El-Morsy, and J. W. Scott
}

\begin{abstract}
First, second, third, and seventh authors: University of Florida, Gulf Coast Research and Education Center, 5007 60th Street E., Bradenton 34203; fourth author: University of Florida, Plant Pathology Department, Gainesville 32611; fifth author: University of Florida, Everglades Research and Education Center, Belle Glade 33430; and sixth author: Plant Pathology Research Institute, Agricultural Research Center, Giza, Egypt.
\end{abstract}

Accepted for publication 8 October 1997.

\begin{abstract}
Jones, J. B., Bouzar, H., Somodi, G. C., Stall, R. E., Pernezny, K., El-Morsy, G., and Scott, J. W. 1998. Evidence for the preemptive nature of tomato race 3 of Xanthomonas campestris pv. vesicatoria in Florida. Phytopathology 88:33-38.

Until recently, tomato race 1 (T1) of Xanthomonas campestris pv. vesicatoria was the only race causing bacterial spot of tomato in Florida. In 1991, tomato race 3 (T3) was first identified in 3 of 13 tomato production fields surveyed. By 1994, T3 was observed in 21 of 28 fields and was the only race identified in 14 fields. In field studies, tomato genotypes with resistance to either T1 or T3 or susceptibility to both were coinoculated with strains of both races. Lesions on 10 plants in each of three replications for each genotype were sampled three times during the experiment; bacterial isolations were made from each lesion, and tomato race identifications were made for each strain. At the third sampling date,

T3 was isolated from $97 \%$ of the lesions on the susceptible genotype Walter and the T1-resistant genotype Hawaii 7998, while T3 was isolated from $23 \%$ of the lesions and $\mathrm{T} 1$ from the remaining $77 \%$ on the $\mathrm{T} 3-$ resistant genotypes PI 128216 and PI 126932. In surface population studies done in growth rooms, suspensions of T1 and T3 were applied alone and in combination to the leaf surfaces of susceptible and resistant genotypes. T1 populations were reduced more than 10-fold when applied in combination with T3, compared with populations that developed when T1 was applied alone. T3 populations were not affected when applied in combination with a T1 strain. In greenhouse studies with the T3-resistant genotype Hawaii 7981, disease was significantly reduced in plants inoculated with $\mathrm{T} 3$ in combination with $\mathrm{T} 1$, compared with plants inoculated with $\mathrm{T} 1$ alone. These results clearly demonstrate the competitive nature of $\mathrm{T} 3$ in the presence of $\mathrm{T} 1$ and help explain the emergence of T3 as a prevalent race in Florida.
\end{abstract}

Bacterial spot of tomato, incited by Xanthomonas campestris pv. vesicatoria, is an important disease in Florida, causing significant yield losses when weather conditions are optimal (22). Control of this disease is extremely difficult, as chemicals do not work well in wet weather $(8,13,14)$, many strains are resistant to copper compounds $(13,17)$, and the pathogen is endemic in Florida (10). As a result, a program was initiated in the 1980 s to identify potential sources of genetic resistance (24). The tomato genotype Hawaii 7998 was found to respond with a hypersensitive reaction when inoculated with typical strains from Florida and was observed to have excellent field resistance to bacterial spot (11). Scott et al. $(25,26)$ initiated a breeding program to incorporate the Hawaii 7998 resistance into commercial genotypes. In 1986, Nagai and Sugimori (20) reported that Hawaii 7998 is susceptible to $X$. campestris pv. vesicatoria in Brazil, and in 1988, the strain was determined to be a new race (33). The Florida strains that were incompatible with Hawaii 7998 (11) and the Brazil strain (33) were designated tomato race 1 (T1) and tomato race 2 (T2), respectively (2). Stall et al. (28) determined that the T1 and T2 strains are quite distinct phenotypically and genotypically. Further characterization by Bouzar et al. (1) showed that these two general groups can be differentiated on the basis of protein profiles. T1 strains are in $X$. campestris pv. vesicatoria group A, have a 32- to $35-\mathrm{kDa}$ protein band, and exhibit negative or weak amylolytic and pectolytic activity, and T2 strains are in $X$. campestris pv. vesica-

Corresponding author: J. B. Jones; E-mail: jbjones@nersp.nerdc.ufl.edu

Publication no. P-1997-1110-02R

(C) 1998 The American Phytopathological Society toria group $\mathrm{B}$, have a $25-$ to $27-\mathrm{kDa}$ protein band, and exhibit strong amylolytic and pectolytic activity. Vauterin et al. (32) reclassified the xanthomonads and placed the A and B strains in $X$. axonopodis pv. vesicatoria and $X$. vesicatoria, respectively.

T2 strains are found in many countries and at several locations in the United States (3), but T2 was not present in Florida, nor were strains typical of group B found in a collection of $X$. campestris pv. vesicatoria strains from Florida isolated over a period of 20 years (4). Thus, the breeding program for field selection of genotypes resistant to $\mathrm{T} 1$ strains from crosses made with Hawaii 7998 continued to be successful.

In 1991 an outbreak of bacterial spot in Florida occurred on Hawaii 7998 and genotypes derived from it. Originally thought to be $\mathrm{T} 2$, because amylolytic and pectolytic activity placed them in group $\mathrm{B}$, the strains were later identified as a new race (tomato race 3 ), distinguished by its ability to produce a hypersensitive reaction in several genotypes, including Hawaii 7981 (12). Recently, T3 strains were determined to have more than $70 \%$ homology to group A strains and would be considered the same species (J. B. Jones, H. Bouzar, J. Sudbury, and P. M. Strickler, unpublished data). T3 strains were originally observed in three fields, including two commercial fields and an experimental field at the Gulf Coast Research and Education Center. T3 strains were found at a very low incidence in the two commercial fields, but at a very high incidence in the experimental field. Efforts to breed for T1 resistance derived from Hawaii 7998 were thwarted by an influx of T3 into the field plots. Furthermore, T3 strains were thought to be more aggressive than $\mathrm{T} 1$ in the field, since $\mathrm{T} 3$ strains were predominant in plots where the plants had been inoculated with T1 strains only (J. B. Jones, H. Bouzar, J. Sudbury, and P. M. Strickler, unpublished data). T3 strains, however, were observed to be anta- 
gonistic to T1 strains in vitro (7) and produce what appears to be a bacteriocin active against $\mathrm{T} 1$ strains (30).

This study was undertaken to demonstrate the importance of T3 strains in Florida by surveying fields from 1991 through 1995, comparing T1 and T3 strains in field and greenhouse studies, and assessing the ability of $\mathrm{T} 3$ strains to survive in the field on crop refuse.

\section{MATERIALS AND METHODS}

Bacterial strains, inoculum production, and inoculation procedure. Bacterial strains used in the experiments were stored longterm at $-80^{\circ} \mathrm{C}$. Inoculum was produced by growing the bacteria on nutrient agar (NA) for $24 \mathrm{~h}$ at $28^{\circ} \mathrm{C}$. Bacterial cells were removed from the agar plates and suspended in $10 \mathrm{mM} \mathrm{MgSO}{ }_{4} \cdot 7 \mathrm{H}_{2} \mathrm{O}$, and the suspensions were standardized to $A_{600}=0.15$ (a concentration of approximately $3 \times 10^{8} \mathrm{CFU} / \mathrm{ml}$ ).

Field survey. Plants in tomato production fields were sampled from 1991 to 1995 in the south central, southwest, and southeast tomato production regions of Florida. Leaves with typical bacterial spot lesions were selected at random from the field. Lesions were triturated in sterile distilled water, and the suspension was streaked onto NA. Yellow colonies typical of X. campestris pv. vesicatoria were selected, and the strains were differentiated by physiological tests (amylolytic and pectolytic activity) as described by Bouzar et al. (3), hypersensitive response (15) on Hawaii 7998 and Hawaii 7981 as described by Jones et al. (12), and indirect enzyme-linked immunosorbent assay (ELISA) (9) reaction to a panel of monoclonal antibodies (MAb) as described by Bouzar et al. (3). This panel included a new monoclonal antibody, designated MAb30, which reacts specifically with T3 strains but not T1 or T2 strains (H. Bouzar and J. B. Jones, unpublished data).

In vitro inhibition of $\mathrm{T} 1$ and $\mathrm{T} 3$ strains. NA plates were inoculated with one of three T3 strains (XV828, XV938, and XV1220) or one of two T1 strains (XV116 and XV153); $10 \mu \mathrm{l}$ of a 24-h-old bacterial suspension grown in nutrient broth at $28^{\circ} \mathrm{C}$ was applied in the center of each plate. The plates were incubated for $48 \mathrm{~h}$ at $28^{\circ} \mathrm{C}$. Indicator bacteria from 24-h-old cultures grown on NA were suspended in $10 \mathrm{mM} \mathrm{MgSO} \cdot \cdot 7 \mathrm{H}_{2} \mathrm{O}$, adjusted to $1 \times 10^{6} \mathrm{CFU} / \mathrm{ml}$, and streaked from the edge of the plate to within $2 \mathrm{~mm}$ of the producer strain, but without contact. The plates were incubated an additional $48 \mathrm{~h}$ at $28^{\circ} \mathrm{C}$, and then inhibition zones were measured. Each test was replicated three times.

Effect of tomato genotype on incidence of $\mathrm{T} 1$ and $\mathrm{T} 3$ strains in field studies. The following cultigens were used: Walter (susceptible to T1 and T3), Hawaii 7998 (resistant to T1 and susceptible to T3), and PI 128216 and PI 126932 (susceptible to T1 and resistant to T3). Two days prior to transplanting to the field, the plants were inoculated with a mixture of T1 strains (XV171, XV1113, XV1114, XV1115, XV1116, and XV1117) or a mixture of T3 strains (XV893, XV896, XV1118, XV1130, XV1136, and

TABLE 1. Survey of tomato fields for the prevalence of tomato race 1 (T1) and tomato race 3 (T3) of Xanthomonas campestris pv. vesicatoria

\begin{tabular}{lrrrrrr}
\hline & \multicolumn{2}{c}{$\begin{array}{c}\text { Number of fields containing } \\
\text { T1, T3, or both races }\end{array}$} & & \multicolumn{2}{c}{$\begin{array}{c}\text { Number (\%) } \\
\text { of strains isolated }\end{array}$} \\
\cline { 2 - 3 } \cline { 5 - 6 } Year & T1 & T1 + T3 & T3 & & \multicolumn{1}{c}{ T1 } & \multicolumn{1}{c}{ T3 } \\
\hline 1991 & 10 & 3 & 0 & & $164(98.8)$ & $2(1.2)$ \\
1992 & 5 & 1 & 3 & & $283(92.2)$ & $24(7.8)$ \\
1993 & 4 & 1 & 9 & & $77(45.8)$ & $91(54.2)$ \\
1994 & 7 & 7 & 14 & & $101(55.2)$ & $82(44.8)$ \\
1995 & 1 & 1 & 5 & $9(45.0)$ & $11(55.0)$ \\
\hline
\end{tabular}

$\mathrm{z}$ The races were identified by infiltrating leaflets of tomato genotypes Hawaii 7998, Hawaii 7981, and Walter with bacterial suspensions adjusted to $1 \times 10^{8} \mathrm{CFU} / \mathrm{ml}$ and determining compatible and incompatible reactions. Strains were also characterized by enzyme-linked immunosorbent assay reactions using monoclonal antibodies that differentiate between $\mathrm{T} 1$ and $\mathrm{T} 3$ strains.
XV1141) by misting a suspension on the abaxial and adaxial leaf surfaces. The inoculated plants were placed in clear polyethylene bags and incubated for $36 \mathrm{~h}$ at $28^{\circ} \mathrm{C}$ with 12 -h light and 12-h dark periods. Transplants were arranged in a completely randomized block design consisting of three replications. In each block, six T1-inoculated plants and six T3-inoculated plants were alternately planted. One leaflet was collected from the top third of each plant on each sampling date, and individual bacterial spot lesions were triturated in sterile water and plated on NA amended with starch. Amylolytic activity was recorded, and the race was determined by ELISA as previously described (10), using T3-specific MAb30 and T1-specific MAb1. Representative strains were infiltrated into the tomato differentials to determine actual race identity.

A second experiment was conducted, in which the following cultigens were used: Sunny (susceptible to T1 and T3), Campbell 28 (susceptible to T1 and T3), and Hawaii 7998. One panel of a leaflet of each plant was infiltrated with a suspension of a nonamylolytic T1 strain (XV929) by means of a hypodermic syringe. Other leaflets were similarly inoculated with an amylolytic T3 strain (XV824). The inoculated transplants were set in the field in six rows, with 10 plants in each row. The plants were grown in the field approximately 40 days, at which time 50 diseased leaflets from recently infected leaves were randomly selected from each of the three genotypes. Individual bacterial spot lesions from each leaflet were triturated in sterilized water and plated on NA. Amylolytic activity was determined for each strain to determine the number of T1 and T3 strains. Selected strains isolated from each cultigen were tested by ELISA for reaction with MAb30 and tested for race by hypersensitive reaction on differential tomato genotypes (12).

Interaction of $\mathrm{T} 1$ and $\mathrm{T} 3$ on resistant and susceptible tomato genotypes in growth room studies. Tomato plants of the genotypes Hawaii 7981 (susceptible to T1 and resistant to T3), Hawaii 7998, and Walter were grown in $10-\mathrm{cm}$ pots for about 4 weeks after transplanting. The plants were misted with one of the following treatments: (i) a suspension consisting of a T3 strain

TABLE 2. Inhibition of strains of Xanthomonas campestris pv. vesicatoria tomato race 1 (T1) by three strains of tomato race 3 (T3) in vitro

\begin{tabular}{|c|c|c|c|c|c|}
\hline \multirow[b]{2}{*}{ Strain } & \multirow[b]{2}{*}{ Race } & \multirow[b]{2}{*}{ Origin $^{y}$} & \multicolumn{3}{|c|}{$\begin{array}{c}\text { Inhibition zone reaction to } X \text {. } \\
\text { campestris pv. vesicatoria } \\
\text { group C strain }{ }^{\mathrm{z}}\end{array}$} \\
\hline & & & XV828 & XV938 & XV1220 \\
\hline XV1 & $\mathrm{T} 1$ & Florida & ++ & ++ & ++ \\
\hline XV12 & $\mathrm{T} 1$ & Florida & +++ & +++ & +++ \\
\hline XV39 & $\mathrm{T} 1$ & Florida & + & ++ & + \\
\hline XV116 & $\mathrm{T} 1$ & Florida & ++ & ++ & + \\
\hline XV127 & $\mathrm{T} 1$ & Florida & +++ & +++ & ++ \\
\hline XV153 & $\mathrm{T} 1$ & Florida & ++ & ++ & +++ \\
\hline XV155 & $\mathrm{T} 1$ & Florida & ++ & ++ & ++ \\
\hline XV225 & $\mathrm{T} 1$ & Guadeloupe & ++ & ++ & + \\
\hline BA26-1 & $\mathrm{T} 1$ & Argentina & ++ & ++ & ++ \\
\hline XV682 & $\mathrm{T} 1$ & Puerto Rico & ++ & ++ & ++ \\
\hline XV798 & $\mathrm{T} 1$ & Virgin Islands & + & + & + \\
\hline XV836 & $\mathrm{T} 1$ & Florida & + & ++ & ++ \\
\hline XV929 & $\mathrm{T} 1$ & Florida & ++ & ++ & + \\
\hline XV1103 & $\mathrm{T} 1$ & Senegal & ++ & ++ & + \\
\hline XV1244 & $\mathrm{T} 1$ & Florida & + & ++ & + \\
\hline XV938 & T3 & Florida & - & - & - \\
\hline XV828 & T3 & Florida & - & - & - \\
\hline XV1220 & T3 & Thailand & - & - & - \\
\hline
\end{tabular}

y XV1103 was provided by N. E. Ahmed, Agricultural Research Cooperation, Gezira Research Station, Wad Medani, Sudan; BA26-1 was provided by B. Canteros, INTA, Bella Vista, Corrientes, Argentina; all other strains were collected by the authors.

${ }^{\mathrm{z}}$ Nutrient agar was inoculated with the T1 and T3 strains $48 \mathrm{~h}$ after application of T3 strains XV828, XV938, and XV1220 to the medium. $-=$ No inhibition; $+=$ inhibition zone less than $5 \mathrm{~mm}$ in diameter; $++=$ inhibition zone 5 to $10 \mathrm{~mm}$ in diameter; +++ = inhibition zone greater than $10 \mathrm{~mm}$ in diameter. 
(XV938) followed by a suspension of a rifampicin-resistant T1 strain $\left(75-3^{\mathrm{R}}\right)$; (ii) a suspension of a T1 strain (75-3) followed by a suspension of a rifampicin-resistant T3 strain $\left(\mathrm{XV93}^{\mathrm{R}}\right)$; (iii) $10 \mathrm{mM} \mathrm{MgSO}{ }_{4} \cdot 7 \mathrm{H}_{2} \mathrm{O}$ followed by a suspension of $75-3^{\mathrm{R}}$; or (iv) $10 \mathrm{mM} \mathrm{MgSO} \mathrm{M}_{4} \cdot 7 \mathrm{H}_{2} \mathrm{O}$ followed by a suspension of $\mathrm{XV} 938^{\mathrm{R}}$. The plants were placed in clear polyethylene bags and incubated in a growth chamber at $28^{\circ} \mathrm{C}$ with 12 -h light and 12 -h dark periods. Individual leaflets were removed 0,24 , and $48 \mathrm{~h}$ after inoculation, placed in $10 \mathrm{ml}$ of sterile $10 \mathrm{mM}$ phosphate buffer in an Erlenmeyer flask, and rotary-shaken for $30 \mathrm{~min}$ to dislodge bacteria from the leaf surface. The washings and their 10-fold dilutions were plated on NA amended with rifampicin $(75 \mu \mathrm{g} / \mathrm{ml})$, and the plates were incubated at $28^{\circ} \mathrm{C}$. The experiment was repeated three times.

In a separate experiment, foliage of Hawaii 7981 plants (susceptible to $\mathrm{T} 1$ and resistant to T3) were misted with $10 \mathrm{mM}$ $\mathrm{MgSO}_{4} \cdot 7 \mathrm{H}_{2} \mathrm{O}$ or a suspension of $\mathrm{T} 3$ strain XV938. The buffertreated plants were then inoculated with a suspension of XV938 or T1 strain 75-3. The plants initially inoculated by misting with XV938 were then sprayed with a suspension of 75-3. They were then placed in clear polyethylene bags, incubated for $36 \mathrm{~h}$ in a growth chamber at $28^{\circ} \mathrm{C}$, and then unbagged and returned to the growth chamber, in which the relative humidity was greater than $90 \%$. The plants were evaluated for disease by counting the lesions on each leaf, weighing the leaf tissue, and determining the number of lesions per gram of leaf tissue. The experiment was repeated three times.

Survival on crop residue. Sunny tomato transplants were inoculated with $\mathrm{XV} 938^{\mathrm{R}}$ and placed in a growth room at $28^{\circ} \mathrm{C}$ with humidity greater than $90 \%$ for $36 \mathrm{~h}$. They were then planted in the field at the beginning of the growing season, in early August. Diseased leaves were collected at the end of the season (December 1994), packaged in paper bags, and wrapped in a plastic screen. The packaged leaves were either buried $15 \mathrm{~cm}$ below the soil surface or left at the soil surface in a fallow field. The tissue was assayed for the marked strain at the time of placement in the field and 15, 30, 60, 120, 180, and 270 days after placement. The samples were shaken in deionized $\mathrm{H}_{2} \mathrm{O}$ on a wrist-action shaker, and serial dilutions of the washings were plated on a selective medium (agar, $15 \mathrm{~g} /$ liter; nutrient broth, $2 \mathrm{~g} /$ liter; yeast extract, $0.1 \mathrm{~g} /$ liter; starch, 4 g/liter; Bravo 720, 15 ll/liter; cycloheximide, 100 mg/liter; and rifampicin, $75 \mathrm{mg} / \mathrm{liter}$ ). This medium had an efficiency of recovery for the marked strain comparable to that of NA supplemented with rifampicin, and it allowed visual detection of amylolytic activity 2 days after plating. The identity of randomly selected colonies was confirmed by ELISA reaction with MAb30.

In another experiment, Sunny tomato plants infected with $\mathrm{XV} 938^{\mathrm{R}}$ were incorporated into the soil, and the field was left undisturbed until the following growing season. Weeds and tomato volunteers growing in that field were screened for the presence of $\mathrm{XV} 938^{\mathrm{R}}$ on the selective medium described above.

\section{RESULTS}

Field survey. In the survey of Florida tomato fields, a dramatic shift in the tomato race composition occurred over a 5-year period (Table 1). In 1991, T3 was found only sporadically and at a low frequency $(<1 \%)$, except in one field at the Gulf Coast Research and Education Center. In 1993 and 1994, the number of T1 and T3 strains was about the same. Few samples were processed in 1995, but the proportion of T3 strains continued to increase.

In vitro inhibition of T1 strains by $\mathbf{T} 3$ strains. All T1 strains were inhibited by the three T3 strains (Table 2); however, there was variation in the size of zone of inhibition. T3 strains did not inhibit other T3 strains. When the two T1 strains were spotted in the centers of NA plates, no inhibition zones were observed with any of the $12 \mathrm{~T} 3$ and $15 \mathrm{~T} 1$ strains tested (data not shown).

Effect of tomato genotype on incidence of T1 and T3 strains in field studies. In Walter tomato coinoculated with $\mathrm{T} 1$ and $\mathrm{T} 3$,
T3 was the prevalent race in lesions approximately 1 month after transplanting (Table 3). In the two T3-resistant genotypes (PI 128216 and PI 126932), the proportion of T3 lesions was quite high in the first two samplings, but declined to $23 \%$ in the final sampling period. In the T1-resistant genotype Hawaii 7998, T3 was isolated from all lesions during the first two sampling periods and from $97 \%$ of the lesions during the last sampling period. In the second experiment, T3 strains were isolated from 48 of 50 lesions on the Hawaii 7998 plants, while neither race was isolated from two of the lesions. On Sunny plants, T1 and T3 were isolated from 1 and 49 of 50 lesions, respectively. On Campbell 28 plants, T3 was isolated from 49 of 50 lesions, while the remaining lesion contained neither strain.

Interaction of $\mathrm{T} 1$ and $\mathrm{T} 3$ strains on resistant and susceptible tomato genotypes in growth room studies. In growth population studies in which Walter tomato plants were inoculated with T1 or T3 individually or in combination, a sharp reduction in surface populations of $\mathrm{T} 1$ occurred after $48 \mathrm{~h}$ when plants were coinoculated with T1 and T3 (Fig. 1A); however, T3 populations were unaffected by coinoculation with $\mathrm{T} 1$. Similar results were observed on Hawaii 7981 plants (Fig. 1B) and Hawaii 7998 plants (Fig. 1C). Similar findings were observed in two other experiments.

In an experiment in which the T3-resistant genotype Hawaii 7981 was inoculated with various combinations of T1 and T3 strains, significantly fewer lesions formed on plants inoculated with T3 followed by $\mathrm{T} 1$ than on plants inoculated with $\mathrm{MgSO}_{4}$ solution and then T1 (Table 4). Plants inoculated with T3 alone had very few lesions. Similar results were found in two additional experiments.

Survival in crop residue. A rifampicin-resistant strain of race T3 $\left(\mathrm{XV} 3^{\mathrm{R}}\right)$ did not survive well in field soil. The population on diseased plant residues placed at the soil surface declined to below the lowest detectable level after 10 months, and the strain could be recovered from similar samples buried in the soil for only up to 2 months after burial (Table 5). Volunteer tomatoes with bacterial spot symptoms were found in the field where tomato plants diseased with strain $\mathrm{XV} 938^{\mathrm{R}}$ were incorporated in the soil by plowing. Strain XV938 ${ }^{\mathrm{R}}$ was recovered from these volunteer plants, but not from weeds growing in the same field.

\section{DISCUSSION}

$X$. campestris pv. vesicatoria race $\mathrm{T} 1$ has been displaced by race $\mathrm{T} 3$ as the prevalent race in many Florida tomato fields. Race shifts of this pathogen in production fields were previously observed in Mexico and Florida (2,21). In 1982, pepper race 2 (P2) was the primary race on pepper in Florida (5), but, by the late 1980s, Pohronezny et al. (21) observed that pepper race 1 (P1) had become dominant in Florida. In 1988, P2 accounted for $89 \%$ of the strains, whereas, in 1989, P2 accounted for only $15 \%$ of the strains.

Shifts in race populations can occur several ways. Pohronezny et al. (21) explained the sudden shift by the introduction of P1 on seed. They reasoned that since the pepper genotypes grown in

TABLE 3. Recovery of Xanthomonas campestris pv. vesicatoria tomato race 3 (T3) from lesions on tomato plants inoculated with strains of tomato race 1 (T1) and T3 and transplanted on 17 August

\begin{tabular}{|c|c|c|c|c|}
\hline \multirow[b]{2}{*}{ Tomato genotype } & \multirow{2}{*}{$\begin{array}{l}\text { Race } \\
\text { resistance }\end{array}$} & \multicolumn{3}{|c|}{ Lesions with T3 $(\%)^{\mathrm{z}}$} \\
\hline & & 17 Sep. & 13 Oct. & 25 Oct. \\
\hline Walter & None & 80 & 100 & 97 \\
\hline Hawaii 7998 & $\mathrm{~T} 1$ & 100 & 100 & 97 \\
\hline PI 128216 & $\mathrm{~T} 3$ & 59 & 41 & 23 \\
\hline PI 126932 & $\mathrm{~T} 3$ & 40 & 57 & 23 \\
\hline
\end{tabular}

${ }_{\mathrm{z}}$ Average percentage recovery of $\mathrm{T} 3$ from lesions on plants in three replications, with 10 lesions assayed per replication. The remaining lesions were caused by T1 strains. T1 and T3 strains were identified by starch hydrolysis and by enzyme-linked immunosorbent assay. 
Florida at that time were susceptible to all known races, and no selection pressure existed that would result in a race change as observed by Dahlbeck and Stall (6), the new race had probably been introduced on seed. Bouzar et al. (2) speculated that seed contamination was responsible for shifts in $X$. campestris pv. vesicatoria races in Mexico. The change in pepper races observed by Pohronezny et al. (21) was dramatic compared with the gradual increase in T3 observed in this study. This may be due to differences in the level of seed transmission of the strains. It is likely that T3 was initially introduced into Florida on seed (12), since it was observed in three different locations in 1991, but was not found among several hundred strains collected over many prior years (4). However, the low incidence of T3 in two of the fields in

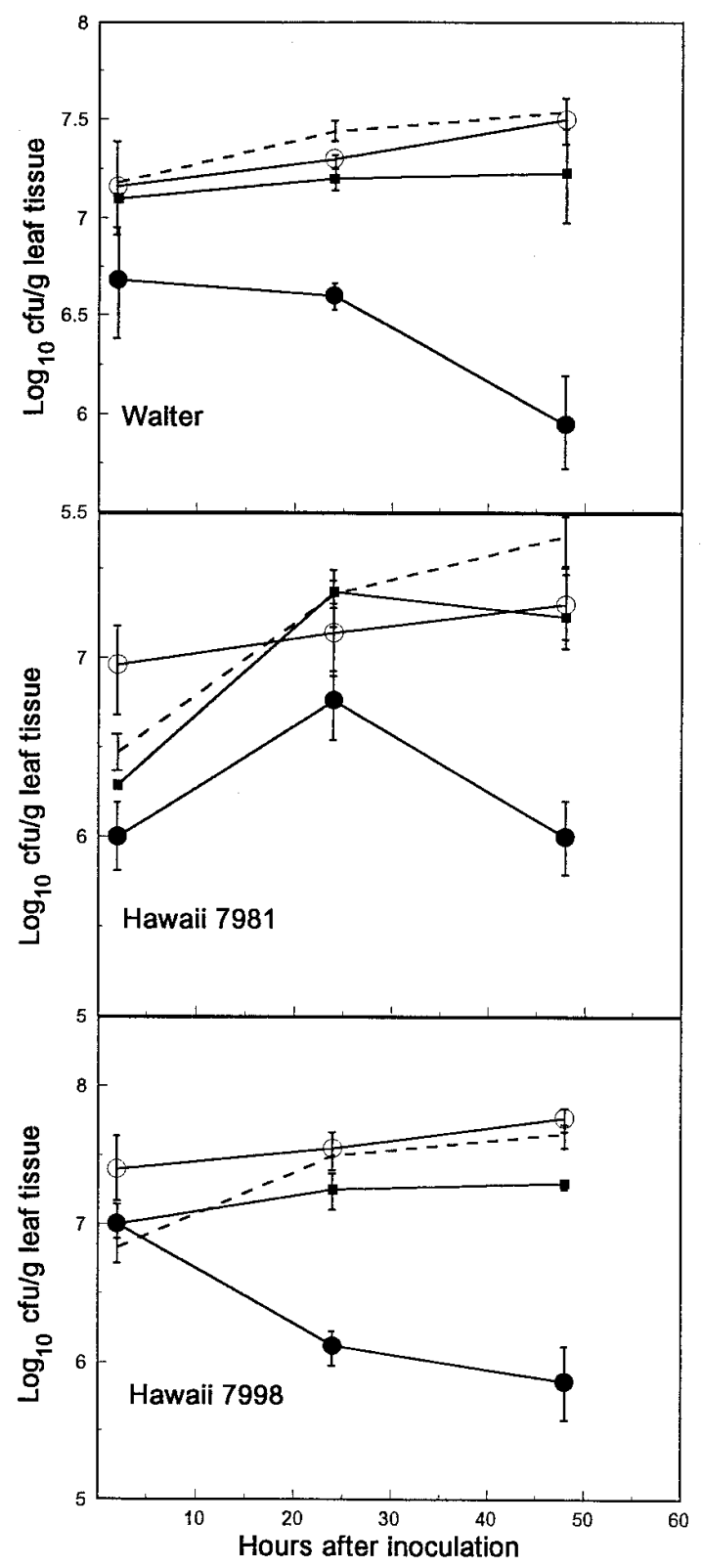

Fig. 1. Growth of strains of Xanthomonas campestris pv. vesicatoria tomato race 1 (T1) and tomato race 3 (T3) when applied alone (after buffer) or in combination to tomato genotypes Walter (susceptible to T1 and T3), Hawaii 7981 (resistant to T3), and Hawaii 7998 (resistant to T1). In dual inoculations, the population of the strain used in the second inoculation is given. The treatments were as follows: T1 inoculum applied immediately before T3

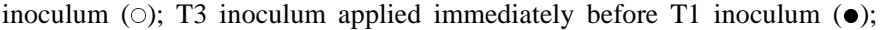
buffer applied immediately before T1 inoculum ( $\boldsymbol{\square})$; and buffer applied immediately before $\mathrm{T} 3$ inoculum $(---)$. The error bars represent the standard deviations.
1991 (data not shown) suggests that that the incidence of T3 on seed was extremely low. Race T1, which has been shown to be endemic in Florida, accounted for most of the disease in the field at that time.

Race shifts also occur when varieties containing new resistance genes are introduced and select for new races that do not contain or have lost the corresponding avirulence gene (18). Kousik and Ritchie (16) noted dramatic race shifts after inoculating resistant pepper genotypes with strains of incompatible races of $X$. campestris pv. vesicatoria. In their study, the race changes in P1 strains occurred as a result of the loss of the plasmid carrying $a v r \mathrm{Bs} 3$ or as a result of insertional inactivation of $a v r \mathrm{Bs} 1$ by IS476 in a P2 strain. In regard to the shift in tomato races at the Gulf Coast Research and Education Center, where a breeding program for incorporating resistance to $\mathrm{T} 1$ was ongoing, $\mathrm{T} 3$ strains had a selective advantage over T1 strains in that they lacked avrRxv, which reacts with the $R x v$ genes in Hawaii 7998. It is unlikely that T1 mutated to T3, since T3 strains are phenotypically (11) and genotypically (J. B. Jones, H. Bouzar, J. Sudbury, and P. M. Strickler, unpublished data) quite different from T1 strains, and such mutation would require the loss of $a v r \mathrm{Rxv}$ (34) from T1 strains and the acquisition of the avirulence gene associated with T3 strains (19). Furthermore, the race shift that occurred throughout the state of Florida could not be the result of the introduction of resistance genes, since all commercial tomato cultivars grown are susceptible to both races.

Some races may also have a competitive advantage over other races in colonizing leaf surfaces. Marco and Stall (17) noted that all P2 strains were copper-resistant, whereas most of the P1 pepper strains were copper-sensitive. Furthermore, Stall et al. (29) determined that avrBs1 was present in the plasmid carrying copper resistance. With the widespread use of copper in Florida, copper resistance gave P2 strains a competitive advantage in Florida and may have been the reason for the high percentage of P2 strains in Florida (5) prior to 1989 . When T3 was initially identified in Florida, strains were sensitive to copper; however, as the organism became more widely distributed in Florida tomato fields, all strains were copper-tolerant (H. Bouzar and J. B. Jones, unpublished data). With most T1 strains in Florida being resistant to copper (17),

TABLE 4. Disease development in tomato genotype Hawaii 7981 treated with $\mathrm{MgSO}_{4}$ or Xanthomonas campestris pv. vesicatoria tomato race 3 (T3) prior to inoculation with tomato race 1 (T1) in a growth chamber

\begin{tabular}{llc}
\hline First treatment & Second treatment & Lesions/g tissue $^{\mathrm{z}}$ \\
\hline $\mathrm{MgSO}_{4}$ & $\mathrm{MgSO}_{4}$ & $1.5 \mathrm{a}$ \\
$\mathrm{MgSO}_{4}$ & $\mathrm{~T} 3$ & $1.2 \mathrm{a}$ \\
$\mathrm{T} 3$ & $\mathrm{~T} 1$ & $20.2 \mathrm{~b}$ \\
$\mathrm{MgSO}_{4}$ & $\mathrm{~T} 1$ & $110.8 \mathrm{c}$ \\
\hline
\end{tabular}

y Hawaii 7981 plants (T3-resistant) were misted with $10 \mathrm{mM} \mathrm{MgSO}_{4}$ or a T3 strain suspended in $10 \mathrm{mM} \mathrm{MgSO}$.

$\mathrm{z}$ Values (averages from one experiment) followed by the same letter are not significantly different according to Duncan's multiple range test, 5\% level.

TABLE 5. Recovery of a rifampicin-resistant strain $\left(\mathrm{XV} 938^{\mathrm{R}}\right)$ of Xanthomonas campestris pv. vesicatoria tomato race 3 (T3) from diseased leaves

\begin{tabular}{lcc}
\hline & \multicolumn{2}{c}{ T3 population $(\mathrm{CFU} / \mathrm{ml})$ recovered from } \\
\cline { 2 - 3 } Sampling date & $\begin{array}{c}\text { Leaves at the } \\
\text { soil surface }\end{array}$ & $\begin{array}{c}\text { Leaves buried } \\
\text { in the soil }\end{array}$ \\
\hline Day 0 & $5 \times 10^{7}$ & $\mathrm{ND}^{\mathrm{y}}$ \\
Day 15 & $5 \times 10^{6}-1 \times 10^{7}$ & $3 \times 10^{5}-1 \times 10^{6}$ \\
Day 30 & $3 \times 10^{6}-5 \times 10^{6}$ & $1 \times 10^{3}$ \\
Day 60 & $1 \times 10^{5}-5 \times 10^{5}$ & $<10^{\mathrm{z}}$ \\
Day 120 & $1 \times 10^{3}$ & $<10$ \\
Day 180 & $1 \times 10^{3}-3 \times 10^{3}$ & $<10$ \\
Day 270 (Sept. 1995) & $<10$ & $<10$ \\
\hline
\end{tabular}

y $\mathrm{ND}=$ not determined.

${ }^{\mathrm{z}}$ Below detection level. 
acquisition of copper resistance by $\mathrm{T} 3$ strains may have been a factor in enabling T3 strains to maintain the competitive advantage over T1 strains in fields where copper bactericides are routinely used. This may help to explain the low incidence of the bacterium in the two commercial fields the first year and the high incidence of T3 strains in the following years.

We demonstrated in this study and previously (7) that T3 strains are antagonistic to $\mathrm{T} 1$ in vitro. It appears to be some type of antibiosis rather than an effect on $\mathrm{pH}$, since $\mathrm{T} 1$ strains were inhibited when assays were done on phosphate-buffered NA (G. El-Morsy, unpublished data). Tudor et al. $(30,31)$ determined that T3 strains produce a bacteriocin-like substance that has activity against T1 strains. With T3 strains being antagonistic to T1 strains in vitro $(7,32)$ and our in planta studies corroborating the antagonistic properties of T3 strains, the shift in race composition toward T3 strains in Florida may, in part, have resulted from antagonism of T3 strains toward T1 strains. In this study, T3 strains were shown to reduce populations of $\mathrm{T} 1$ strains on leaf surfaces of three tomato genotypes coinoculated with strains of both races. In contrast, T1 strains did not significantly affect T3 populations on any of the tomato genotypes. When the T3-resistant genotype was inoculated with a $\mathrm{T} 1$ or a $\mathrm{T} 3$ strain or coinoculated with strains of both races, it was clear that $\mathrm{T} 3$ was inhibitory to $\mathrm{T} 1$ from the reduced number of lesions on coinoculated plants, compared with those inoculated with T1 alone. Our field studies also showed that T3 strains are more competitive than $\mathrm{T} 1$ strains. When isolations were made from lesions on susceptible plants inoculated with both races, T3 was the predominant strain recovered.

Tudor-Nelson et al. (31) determined that more than one bacteriocin is produced by $\mathrm{T} 3$ strains, but their role in the interaction between T1 and T3 strains is not known. Bacteriocin-producing strains may have a competitive advantage over nonproducing strains. Treatment of rice plants with an avirulent, bacteriocinogenic strain of $X$. oryzae pv. oryzae reduced bacterial blight incidence and disease severity when plants were inoculated with bacteriocin-sensitive strains (23). Smidt and Vidaver (27) observed a significant reduction in a bacteriocin-sensitive strain of Pseudomonas syringae when red kidney bean stems were coinoculated with this strain and a bacteriocin-producing strain.

In the survival studies, the T3 strain was detected approximately 6 months after diseased tissue was placed in the field; however, T3 did not appear to survive long enough to be a problem on the following crop. Although the bacterium was recovered from volunteer tomatoes, it was not detected on weed species present in the field. Because neither T1 nor T3 strains appear to survive from one growing season to the next (10), the increased prevalence of $\mathrm{T} 3$ compared with $\mathrm{T} 1$ in production areas cannot be explained by different survival capabilities, but it appears to be the result of the competitive nature of $\mathrm{T} 3$ in the presence of $\mathrm{T} 1$.

\section{ACKNOWLEDGMENTS}

Florida Agricultural Experiment Station Journal Series R-05433. We thank R. O. Kelly for his technical assistance. This research was supported by grant 93-34135-8606 from the U.S. Department of Agriculture Special Research Grants, Tropical and Subtropical Agricultural Research agreement.

\section{LITERATURE CITED}

1. Bouzar, H., Jones, J. B., Minsavage, G. V., Stall, R. E., and Scott, J. W. 1994. Proteins unique to phenotypically distinct groups of Xanthomonas campestris pv. vesicatoria revealed by silver staining. Phytopathology 84:39-44.

2. Bouzar, H., Jones, J. B., Somodi, G. C., Stall, R. E., Daouzli, N., Lambe, R. C., Felix-Gastelum, R., Trinidad-Correa, R. 1996. Diversity of Xanthomonas campestris pv. vesicatoria in tomato and pepper fields of Mexico. Can. J. Plant Pathol. 18:75-77.

3. Bouzar, H., Jones, J. B., Stall, R. E., Hodge, N. C., Minsavage, G. V., Benedict, A. A., and Alvarez, A. M. 1994. Physiological, chemical, sero- logical, and pathogenic analyses of a worldwide collection of Xanthomonas campestris pv. vesicatoria strains. Phytopathology 84:663-671.

4. Canteros, B. I. 1990. Diversity of plasmids and plasmid-encoded phenotypic traits in Xanthomonas campestris pv. vesicatoria. Ph.D. dissertation. University of Florida, Gainesville.

5. Cook, A. A., and Stall, R. E. 1982. Distribution of races of Xanthomonas vesicatoria pathogenic on pepper. Plant Dis. 66:388-389.

6. Dahlbeck, D., and Stall, R. E. 1979. Mutations for change of race in cultures of Xanthomonas vesicatoria. Phytopathology 69:634-636.

7. El-Morsy, G. A., Somodi, G. C., Scott, J. W., Stall, R. E., and Jones, J. B. 1994. Aggressiveness of Xanthomonas campestris pv. vesicatoria tomato race 3 (T3) strains over tomato race 1 (T1) strains: Evidence for antagonism. (Abstr.) Phytopathology 84:1094.

8. Jones, J. B., and Jones, J. P. 1985. The effect of bactericides, tank mixing time and spray schedule on bacterial leaf spot of tomato. Proc. Fla. State Hortic. Soc. 98:244-247.

9. Jones, J. B., Minsavage, G. V., Stall, R. E., Kelly, R. O., and Bouzar, H. 1993. Genetic analysis of a DNA region involved in expression of two epitopes associated with lipopolysaccharide in Xanthomonas campestris pv. vesicatoria. Phytopathology 83:551-556.

10. Jones, J. B., Pohronezny, K. L., Stall, R. E., and Jones, J. P. 1986. Survival of Xanthomonas campestris pv. vesicatoria in Florida on tomato crop residue, weeds, seeds, and volunteer tomato plants. Phytopathology 76:430-434.

11. Jones, J. B., and Scott, J. W. 1986. Hypersensitive response in tomato to Xanthomonas campestris pv. vesicatoria. Plant Dis. 70:337-339.

12. Jones, J. B., Stall, R. E., Scott, J. W., Somodi, G. C., Bouzar, H., and Hodge, N. C. 1995. A third tomato race of Xanthomonas campestris pv. vesicatoria. Plant Dis. 79:395-398.

13. Jones, J. B., Woltz, S. S., Jones, J. P., and Portier, K. L. 1991. Population dynamics of Xanthomonas campestris pv. vesicatoria on tomato leaflets treated with copper bactericides. Phytopathology 81:714-719.

14. Jones, J. B., Woltz, S. S., Kelly, R. O., and Harris, G. 1991. The role of ionic copper, total copper, and select bactericides on control of bacterial spot of tomato. Proc. Fla. State Hortic. Soc. 104:257-259.

15. Klement, Z. 1982. Hypersensitivity. Pages 149-177 in: Phytopathogenic Prokaryotes. Vol. 2. M. S. Mount and G. H. Lacy, eds. Academic Press, New York.

16. Kousik, C. S., and Ritchie, D. F. 1996. Race shift in Xanthomonas campestris pv. vesicatoria within a season in field-grown pepper. Phytopathology 86:952-958.

17. Marco, G. M., and Stall, R. E. 1983. Control of bacterial spot of pepper initiated by strains of Xanthomonas campestris pv. vesicatoria that differ in sensitivity to copper. Plant Dis. 67:779-781.

18. Mew, T. W., Vera Cruz, C. M., and Medalla, E. S. 1992. Changes in race frequency of Xanthomonas oryzae pv. oryzae in response to rice cultivars planted in the Philippines. Plant Dis. 76:1029-1032.

19. Minsavage, G. V., Jones, J. B., and R. E. Stall. 1996. Cloning and sequencing of an avirulence gene (avrRxv3) isolated from Xanthomonas campestris pv. vesicatoria tomato race 3. (Abstr.) Phytopathology (Suppl.) 86:S15.

20. Nagai, H., and Sugimori, M. H. 1986. Suscetibilidade dos tomateiros 'H 7998' e 'C-28' a pústula bacteriana (Xanthomonas campestris pv. vesicatoria) em Sâo Paulo. (Abstr.) Hortic. Bras. 4:62.

21. Pohronezny, K., Stall, R. E., Canteros, B. I., Kegley, M., Datnoff, L. E., and Subramanya, R. 1992. Sudden shift in the prevalent race of Xanthomonas campestris pv. vesicatoria in pepper fields in southern Florida. Plant Dis. 76:118-120.

22. Pohronezny, K., and Volin, R. B. 1983. The effect of bacterial spot on yield and quality of fresh market tomatoes. HortScience 18:69-70.

23. Sakthivel, N., and Mew, T. W. 1991. Efficacy of bacteriocinogenic strains of Xanthomonas campestris pv. oryzae on the incidence of bacterial blight disease of rice (Oryza sativa L.). Can. J. Microbiol. 37:764-768.

24. Scott, J. W., and Jones, J. B. 1986. Sources of resistance to bacterial spot [Xanthomonas campestris pv. vesicatoria (Doidge) Dye] in tomato. HortScience 21:304-306.

25. Scott, J. W., Jones, J. B., and Somodi, G. C. 1991. Disease severity of tomato hybrids heterozygous or homozygous for resistance to bacterial spot: commercial outlook. Proc. Fla. State Hortic. Soc. 104:259-262.

26. Scott, J. W., Somodi, G. C., and Jones, J. B. 1989. Genetic resistance to bacterial spot in tomato. Pages 200-207 in: Proc. Tomato and Pepper Production in the Tropics. S. K. Green, ed. AVRDC, Shanhua, Tainan, Taiwan.

27. Smidt, M. L., and Vidaver, A. K. 1982. Bacteriocin production by Pseudomonas syringae PS W-1 in plant tissue. Can. J. Microbiol. 28:600-604.

28. Stall, R. E., Beaulieu, C., Egel, D., Hodge, N. C., Leite, R. P., Minsavage, G. V., Bouzar, H., Jones, J. B., Alvarez, A. M., and Benedict, A. A. 1994. Two genetically diverse groups of strains are included in a pathovar of Xanthomonas campestris. Int. J. Syst. Bacteriol. 44:47-53. 
29. Stall, R. E., Loschke, D. C., and Jones, J. B. 1986. Linkage of copper resistance and avirulence loci on a self-transmissible plasmid in Xanthomonas campestris pv. vesicatoria. Phytopathology 76:240-243.

30. Tudor, S. M. 1995. An analysis of antagonism in tomato race three strains of Xanthomonas campestris pv. vesicatoria. M.Sc. thesis. University of Florida, Gainesville.

31. Tudor-Nelson, S. M., Jones, J. B., Minsavage, G. V., and Stall, R. E. 1995. Characterization of antagonism of tomato race 3 strains of Xanthomonas campestris pv. vesicatoria to other strains of the same bacterium. (Abstr.) Phytopathology 85:1148.
32. Vauterin, L., Hoste, B., Kersters, K., and Swings, J. 1995. Reclassification of Xanthomonas. Int. J. Syst. Bacteriol. 45:472-489.

33. Wang, J. F., Jones, J. B., Scott, J. W., and Stall, R. E. 1990. A new race of the tomato group of strains of Xanthomonas campestris pv. vesicatoria. (Abstr.) Phytopathology 80:1070.

34. Whalen, M. C., Wang, J. F., Carland, F. M., Heiskell, M. E., Dahlbeck, D., Minsavage, G. V., Jones, J. B., Scott, J. W., Stall, R. E., and Staskawicz, B. J. 1993. Avirulence gene avrRxv from Xanthomonas campestris pv. vesicatoria specifies resistance on tomato line Hawaii 7998. Mol. Plant-Microbe Interact. 6:616-627. 